DOI: $10.24850 / j-$ tyca-2020-05-07

Articles

\title{
Groundwater quality and associated health risks in flood affected public schools: A case study of district Sanghar, Pakistan
}

\section{Calidad del agua subterránea y riesgos de salud asociados en las escuelas públicas afectadas por inundaciones: un estudio de caso del distrito Sanghar, Pakistán}

Muhammad Sarfraz ${ }^{1}$, ORCID: https://orcid.org/0000-0002-68715964

Nargis Sultana ${ }^{2}$

Muhammad Ilyas Tariq ${ }^{3}$

1Pakistan Council of Research in Water Resources, MoST, Sargodha, Pakistan, Department of Chemistry, University of Sargodha, Sargodha, Pakistan, sarfrazzed@gmail.com

2Department of Chemistry, University of Sargodha, Sargodha, Pakistan, nargissultana1@yahoo.co.uk

${ }^{3}$ Department of Chemistry, University of Sargodha, Sargodha, Pakistan, tariqmi2000@yahoo.com

Corresponding author: Muhammad Sarfraz, sarfrazzed@gmail.com 


\section{Tecnología y
Ciencias $₫$ Agua}

2020, Instituto Mexicano de Tecnología del Agua Open Access bajola licencia CC BY-NC-SA 4.0 (https://creativ ecommons.org/licenses/by-nc-sa/4.0/)

\section{Abstract}

Drinking water quality is of vital importance for the healthy life of a community especially if consumer is a teenager. In order to compare groundwater profile of flooded area (FA) and non-flooded area (NFA) of district Sanghar, 120 water samples from public schools were collected and investigated for physico-chemical parameters, essential metals, trace elements and microbiological indicators. Analysis data revealed that $47 \%$ samples in FA were contaminated with faecal coliform bacteria as compared to only $8.3 \%$ in NFA. On the other hand, chemical indicators like TDS, $\mathrm{Ca}, \mathrm{Na}, \mathrm{K}, \mathrm{SO}_{4}, \mathrm{Mg}$ and hardness were higher in FA. Comparison of trace elements content with WHO guidelines revealed that concentration of $\mathrm{Fe}$, As and $\mathrm{Zn}$ was higher in $66.7 \%, 31.7 \%$ and $13.3 \%$ water samples, respectively in FA whereas content of these elements was also on higher side in $3.3 \%, 23.3 \%$ and $1.7 \%$ samples in NFA, respectively. Health risk assessment due to high concentration of Fe, As and Zn showed that As HRI>1, for children in 35 and $23 \%$ water samples in FA and NFA, respectively.

Keywords: Contamination, potable water, risk assessment, Sindh, trace metals.

\section{Resumen}

La calidad del agua potable es de vital importancia para la vida saludable de una comunidad, especialmente si el consumidor es un adolescente. Para comparar el perfil de las aguas subterráneas del área inundada (FA) y el área no inundada (NFA) del distrito de Sanghar, se recolectaron e investigaron 120 muestras de agua de escuelas públicas para determinar parámetros fisicoquímicos, metales esenciales, oligoelementos e indicadores microbiológicos. Los datos del análisis 
revelaron que $47 \%$ de las muestras en FA estaba contaminada con bacterias coliformes fecales en comparación con sólo 8.3\% en NFA. Por otro lado, los indicadores químicos como TDS, Ca, Na, K, SO4, Mg y dureza fueron más altos en FA. La comparación del contenido de elementos traza con las pautas de la OMS reveló que la concentración de Fe, As y $\mathrm{Zn}$ fue mayor en $66.7,31.7$ y $13.3 \%$ de muestras de agua, respectivamente, en $\mathrm{FA}$, mientras que el contenido de estos elementos también estuvo en el lado superior en $3.3,23.3$ y $1.7 \%$ de muestras en NFA, respectivamente. La evaluación del riesgo para la salud debido a la alta concentración de Fe, As y Zn mostró que As HRI > 1, para niños en 35 y $23 \%$ de muestras de agua en FA y NFA, respectivamente.

Palabras clave: contaminación, agua portátil, evaluación de riesgos, Sindh, trazas de metales.

Received: $10 / 08 / 2018$

Accepted: $23 / 02 / 2020$

\section{Introduction}

According to an estimate, about $70 \%$ of people rely on groundwater for their drinking and other household use in Pakistan (Malik, Azam, \& Saboor, 2010). In general, quality of groundwater varies from one place 


\section{Tecnología y
Ciencias $₫$ Agua}

2020, Instituto Mexicano de Tecnología del Agua Open Access bajola licencia CC BY-NC-SA 4.0 (https://creativ ecommons.org/licenses/by-nc-sa/4.0/)

to another, sometimes depending upon seasonal changes, the nature of soil, rocks and surfaces through which water flows (Thivya, Chidambaram, Thilagavathi, Nepolian, \& Adithya, 2014). During flood or rainy season, surface water carrying various types of wastes, chemicals, minerals and other pollutants makes its way to groundwater. This mixing or seepage of polluted surface water into groundwater causes contamination of groundwater sources and aquifer. Consumption of this polluted water contribute to about $80 \%$ of waterborne diseases such as hepatitis, diarrhea, dental caries, oral hygiene and anemia in children (Memon, Soomro, Akhtar, \& Memon, 2011). A study conducted by Djaouda et al. (2014) showed possible contamination of well water by human wastes from the traditional latrines system, and animal manure. A number of other studies have also been documented on severe contamination of drinking water sources with hazardous pathogenic bacteria like Shigella sp., $V$. cholerae, $P$. aeruginosa, Salmonella, and $S$. aureus in different areas of Pakistan caused by recent floods, which have resulted diseases like diarrhea, typhoid fever, cholera, dysentery, food poisoning, gastroenteritis, and other serious infections (Baig, Xu, \& Khan, 2012; Khan, Ali, Ullah, \& Ayaz, 2013; Saeed \& Attaullah, 2014). Women and children are more prone to waterborne diseases and it is estimated that in developing countries, 1.7 million deaths per year which include $90 \%$ children are attributed to diarrheal disease due to lack of safe drinking water (WHO, 2004). A study conducted in Charsadda district of KPK, Pakistan revealed that faecal contamination of drinking water was the reason behind the occurrence of a number of waterborne diseases in the region (Khan et al., 2013).

Although major ions and elements present in drinking water are essential nutrients for humans, however, beyond certain limit these 
pose serious health hazards. Higher concentrations of $\mathrm{SO}_{4}$ with $\mathrm{Mg}$ and $\mathrm{Na}$ impair water taste and have a laxative effect. Similarly, it has been investigated that high concentrations of $\mathrm{Na}$ may increase blood pressure (Azizullah, Khattak, Richter, \& Häder, 2011). Trace elements if ingested in excess can cause serious health implications depending upon nature and quantity of the metal ingested. Therefore, it is important to investigate potential health impacts associated with various water contaminants. Estimation of heavy metals concentration and health risk assessment have been carried out in various studies which revealed that overall all of these metals in excess concentration are toxic (Venkatramanan, Chung, Kim, Prasanna, \& Hamm, 2015). About 200 million people around the world are at the health risk of As poisoning due to intake of As rich water (Rahman, Naidu, \& Bhattacharya, 2009a). A large number of other investigations have also been carried out to evaluate physicochemical and microbiological quality of drinking water and possible health risks. Most of water samples analyzed in these studies were found unfit for human consumption on grounds of either chemical and/or microbiological contamination (Oyem, Oyem, \& Usese, 2015; Alamgir, Khan, Schilling, Shaukat, \& Shahab, 2016; Mohsin, Safdar, Asghar, \& Jamal, 2013; Sarfraz, Sultana, Jamil, \& Ashraf, 2016; Sarfraz, Sultana, \& Jamil, 2018a; Sarfraz, Sultana, \& Tariq, 2018b).

Rain and flood water carry out and mix human and animal's faecal wastes to groundwater which may carry pathogens and ultimately contaminates the water sources in the region. Besides this, pollutants from fertilizers, industrial wastes, metallic elements due to corrosion or decay of metallic infrastructure and other chemical constitutes make their route to groundwater. All these occurrences cause contamination of groundwater sources with different types of 
pollutants. Hence, we have designed our project to evaluate potable groundwater quality in flooded area (FA) and non-flooded area (NFA) of district Sanghar, Pakistan, by performing physico-chemical and microbial investigations. Health risk assessment of all water samples collected from 120 public schools situated in rural areas of both FA and NFA locations was also carried out to understand risks associated with human consumption of this water.

\section{Materials and methods}

\section{Study area}

Sanghar, one of the largest district of Sindh province is located at $26^{\circ}$ $02^{\prime} 00^{\prime \prime} \mathrm{N}$ and $71^{\circ} 11^{\prime} 36^{\prime \prime} \mathrm{E}$. This district is almost located in the centre of Sindh and is bounded by India on east side. Heavy rains in 2016 and overflowing water of river Sindh flooded a large area of Sanghar, Pakistan, causing damage to infrastructure, agricultural land and farmland in rural areas of this district. In rural areas of the district Sanghar, drinking water in public schools is available directly from various groundwater sources including hand pumps and motor pumps without any further water treatment. Water samples from available groundwater sources of public schools located in 120 villages (60 FA 
and 60 NFA) were collected and analyzed for various water quality parameters. From each site, three water samples were collected in clean poly propylene bottles $(600 \mathrm{ml})$ for evaluation of physicochemical, trace elements and aesthetic parameters whereas water samples for microbiological analysis were collected in sterilized bottles $(250 \mathrm{ml})$ and stored in ice box. Water samples for $\mathrm{As}$ and $\mathrm{NO}_{3}$ were preserved with $\mathrm{HNO}_{3}$ and boric acid solutions respectively.

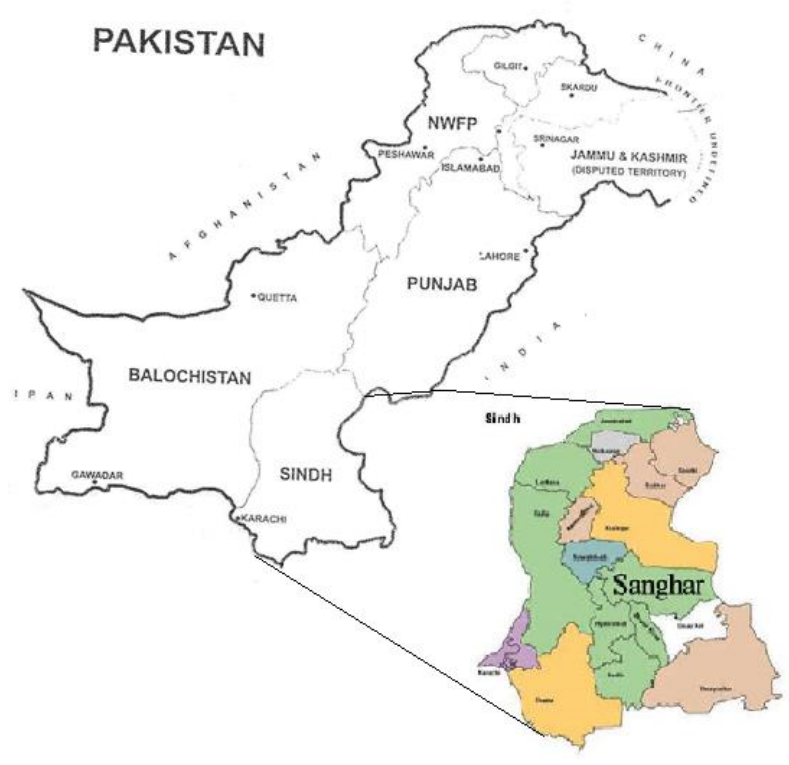

Physico-chemical analysis

Aesthetic and physical parameters like color, taste, electrical conductivity $(\mathrm{EC})$, turbidity and $\mathrm{pH}$ were recorded at the sampling site using respective field testing instrument. All other water quality Tecnología y ciencias del agua, ISSN 2007-2422, 11(5), 274-297. DOI:10.24850/j-tyca-2020-05-0728 
parameters were recorded in laboratory. Briefly, titrimetric analysis was carried out against ethylene diamine tetraacetate (EDTA) for estimation of $\mathrm{Ca}, \mathrm{Mg}$ and hardness, silver nitrate $\left(\mathrm{AgNO}_{3}\right)$ for chloride determination and $\mathrm{HCl}$ solution for estimation of alkalinity. UV-VIS spectrophotometer was used for analysis of $\mathrm{NO}_{3}$ and $\mathrm{SO}_{4}$ by taking absorbance at 220 and $450 \mathrm{~nm}$ respectively. Analysis of $\mathrm{Na}$ and $\mathrm{K}$ was achieved by using flame photometer and other trace elements like Fe, $\mathrm{Zn}$ and As were analyzed on atomic absorption spectrophotometer (AAS). APHA standard methods for examination of water and wastewater were employed to conduct analysis and calculation of results after proper calibration and standardization of instruments (APHA, 2005).

\section{Microbiological analysis}

Water samples were subject to analysis of total coliforms and faecal coliform by using membrane filtration method (USEPA, 2002). Each water sample $(100 \mathrm{ml})$ was filtered using $0.45 \mu \mathrm{m}$ paper filters and these filters were placed on $\mathrm{mENDO}$ and $\mathrm{mFC}$ agar and plates were incubated aerobically. Typical coliform colonies having pink to dark red color with metallic sheen and faecal coliform colonies having blue color were counted afterincubation for $24 \mathrm{~h}$ at $35^{\circ} \mathrm{C}$ and $45{ }^{\circ} \mathrm{C}$, respectively. 


\section{Reagent and instrumentation}

All chemicals and reagent used for the study were of analytical grade and calibration of all instruments was done prior to analysis. Instruments and methods employed for evaluation of chemical parameters includes Jenway, 350 pH meter EU, HANNA HI 99300 Italy EC meter, Louibond PCH63739 Germany turbidity meter, Ca, Mg, Cl, alkalinity and hardness by titration method. $\mathrm{Na}$ and $\mathrm{K}$ on Flame Photometer Italy, Analysis of $\mathrm{SO}_{4}, \mathrm{Fe}$ and $\mathrm{NO}_{3}$ were performed on Optizen 2120 UV Plus Spectrophotometer, Mecasy Co. Ltd. Korea. Atomic absorption spectrophotometer was used for analysis of As and $\mathrm{Zn}$. TDS was calculated by addition of cations and anions and coliform and faecal coliform by membrane filtration assembly.

\section{Health risk assessment}

Chronic daily intake (CDI) and health risk index (HRI) of trace metals was calculated by using the equation given below (Shah, Ara, Muhammad, Khan, \& Tariq, 2012):

$$
\text { ChronicDailyIntake }(C D I)=\frac{M c \times L w}{W b}
$$


where Mc $(\mu \mathrm{g} / \mathrm{l})$ is the metal concentration in water while Lw (I/day) is daily water intake that is considered as $1 \mathrm{~L} /$ day and $2 \mathrm{~L}$ /day for child and adult respectively, and $\mathrm{Wb}(\mathrm{kg})$ is body weight that is assumed as $32.7 \mathrm{~kg}$ for child and $72 \mathrm{~kg}$ for adult (Khan, Rehman, Khan, Khan, \& Shah, 2010). To address chronic health problems, the health risk index was calculated by using below equation:

$$
\text { Health Risk Index }(\mathrm{HRI})=\frac{C D I}{R f D} \times 0.001
$$

where CDI is chronic daily intake; RfD is the reference dose for oral toxicity which is $0.0003,0.7$ and $0.3 \mathrm{mg} \cdot \mathrm{kg}^{-1}$. day ${ }^{-1}$ for As, Fe and $\mathrm{Zn}$ respectively and HRI is measured health risk index, and 0.001 is the conversion factor for downscaling the reference dose (RfD) from $\mathrm{mg}$ to $\mu \mathrm{g} . \mathrm{HRI}<1$ will be the limit for safe mode of water consumption.

\section{Results and discussion}

Water samples from 120 public schools were subject to investigation for physico-chemical water quality parameters (color, odor, $\mathrm{pH}, \mathrm{EC}$, turbidity, $\mathrm{Cl}$, alkalinity, $\mathrm{NO}_{3}, \mathrm{SO}_{4}$ and TDS), essential metals (Ca, $\mathrm{Mg}$, $\mathrm{Na}$ and $\mathrm{K}$ ) and trace elements ( $\mathrm{Fe}, \mathrm{Zn}$ and $\mathrm{As}$ ) in comparison to WHO 
guidelines. Analysis results of all water samples are presented in Table 1, Table 2, and Figure 1 and Figure 2. Microbiological analysis of all water samples was also carried out to assess coliform and faecal coliform organisms.

Table 1. Presentation of chemical parameters in FA and NFA samples.

\begin{tabular}{|c|c|c|c|c|c|c|c|c|}
\hline \multicolumn{2}{|c|}{ Parameters } & $\begin{array}{c}\mathrm{Ca} \\
(\mathrm{mg} / \mathrm{l})\end{array}$ & $\begin{array}{c}M g \\
(\mathrm{mg} / \mathrm{l})\end{array}$ & $\begin{array}{c}\mathrm{Na} \\
(\mathrm{mg} / \mathrm{l})\end{array}$ & $\begin{array}{c}\mathrm{K} \\
(\mathrm{mg} / \mathrm{l})\end{array}$ & $\begin{array}{c}F e \\
(\mathrm{mg} / \mathrm{l})\end{array}$ & $\begin{array}{c}\text { As } \\
(\mathrm{mg} / \mathrm{I})\end{array}$ & $\begin{array}{c}\mathrm{Zn} \\
(\mathrm{mg} / \mathrm{l})\end{array}$ \\
\hline & Min. & 8 & 12.15 & 26 & 1 & 0.1 & 0.7 & 0.3 \\
\hline \multirow[t]{3}{*}{ FA } & Max. & 416 & 315.9 & 1000 & 55 & 2 & 18.5 & 4.2 \\
\hline & Mean & 116.2 & 84.3 & 275.5 & 10.1 & 0.5 & 7.5 & 1.69 \\
\hline & Min. & 8 & 9.72 & 27 & 3 & 0.1 & 0.45 & 0.3 \\
\hline \multirow[t]{2}{*}{ NFA } & Max. & 176 & 97.2 & 410 & 68 & 0.4 & 22.5 & 3.2 \\
\hline & Mean & 63.1 & 35.3 & 124.9 & 7.5 & 0.2 & 5.7 & 1.26 \\
\hline
\end{tabular}

Table 2. Presentation of metallic elements in FA and NFA samples.

\begin{tabular}{ccccccccc}
\hline Parameters & $\begin{array}{c}\text { Ec } \\
(\boldsymbol{\mu S} / \mathbf{c m})\end{array}$ & $\begin{array}{c}\text { Hard. } \\
(\mathbf{m g} / \mathbf{l})\end{array}$ & $\begin{array}{c}\text { TDS } \\
(\mathbf{m g} / \mathbf{l})\end{array}$ & $\begin{array}{c}\mathbf{S O}_{4} \\
(\mathbf{m g} / \mathbf{l})\end{array}$ & $\begin{array}{c}\mathrm{NO}_{3} \\
(\mathbf{m g} / \mathbf{l})\end{array}$ & $\begin{array}{c}\mathrm{Cl} \\
(\mathbf{m g} / \mathbf{l})\end{array}$ & $\begin{array}{c}\text { Alkal. } \\
(\mathbf{m g} / \mathbf{l})\end{array}$ \\
\hline \multirow{2}{*}{ FA } & Min. & 478 & 80 & 242.1 & 28 & 0.0 & 31.5 & 110 \\
& Max. & 6335 & 2100 & 3996.7 & 1230 & 10.5 & 1575 & 560 \\
& Mean & 2324.8 & 638 & 1473.1 & 397.2 & 1.2 & 406.7 & 295.5 \\
& Min. & 391 & 60 & 232.6 & 26 & 0.0 & 24.5 & 100 \\
\multirow{2}{*}{ NFA } & Max. & 5152 & 760 & 1500.4 & 542 & 4.9 & 427 & 420 \\
& Mean & 1410.3 & 304.9 & 699.5 & 211.5 & 0.5 & 105.8 & 248.9 \\
\hline
\end{tabular}


2020, Instituto Mexicano de Tecnología del Agua Open Access bajola licencia CC BY-NC-SA 4.0 (https://creativ Tecnología y

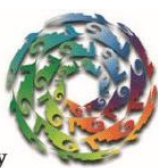
Open Access bajola licencia CC BY-NC-SA
ecommons.org/licenses/by-nc-sa/4.0/)

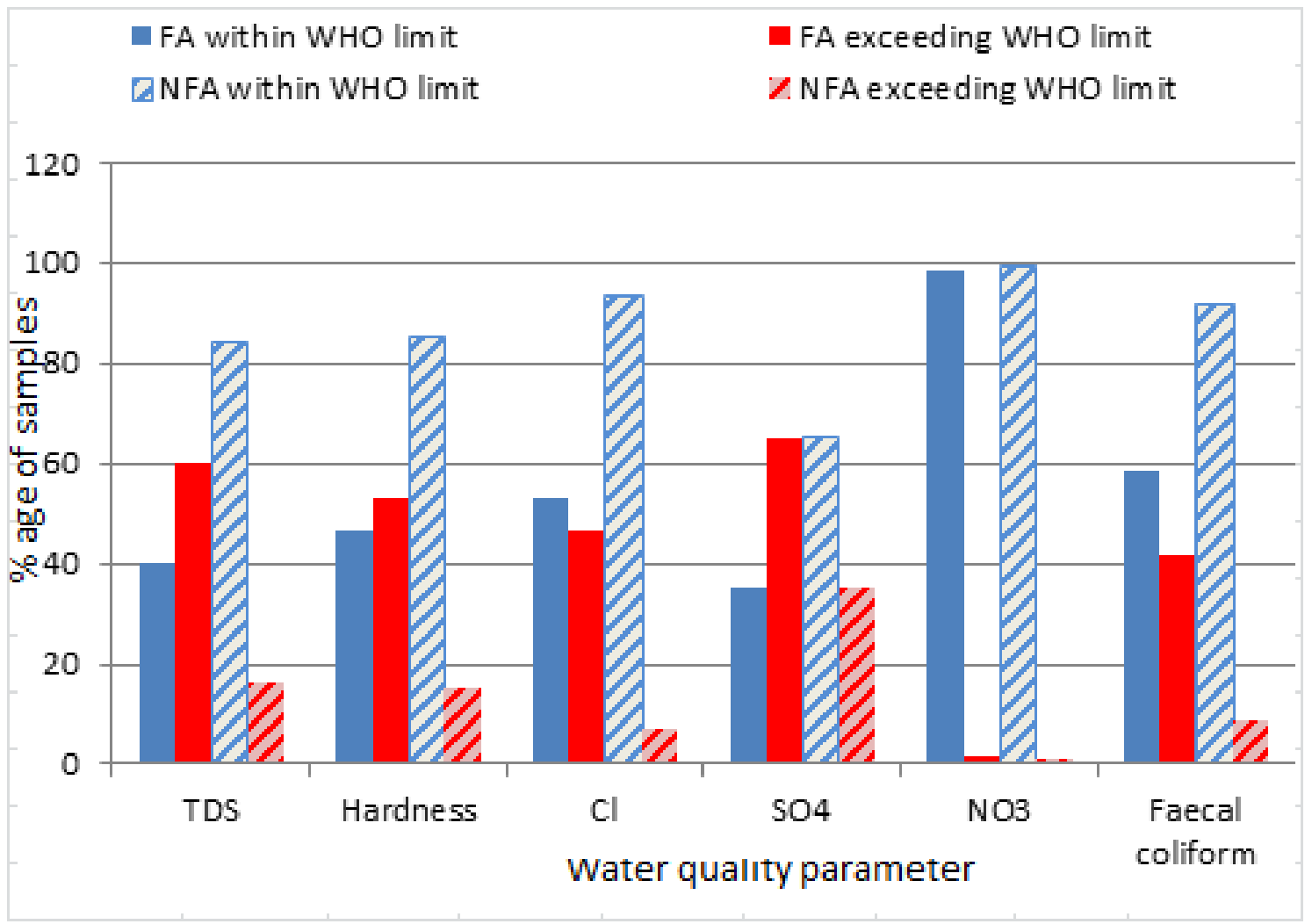

Figure 1. Comparison of water samples results in FA and NFA. 


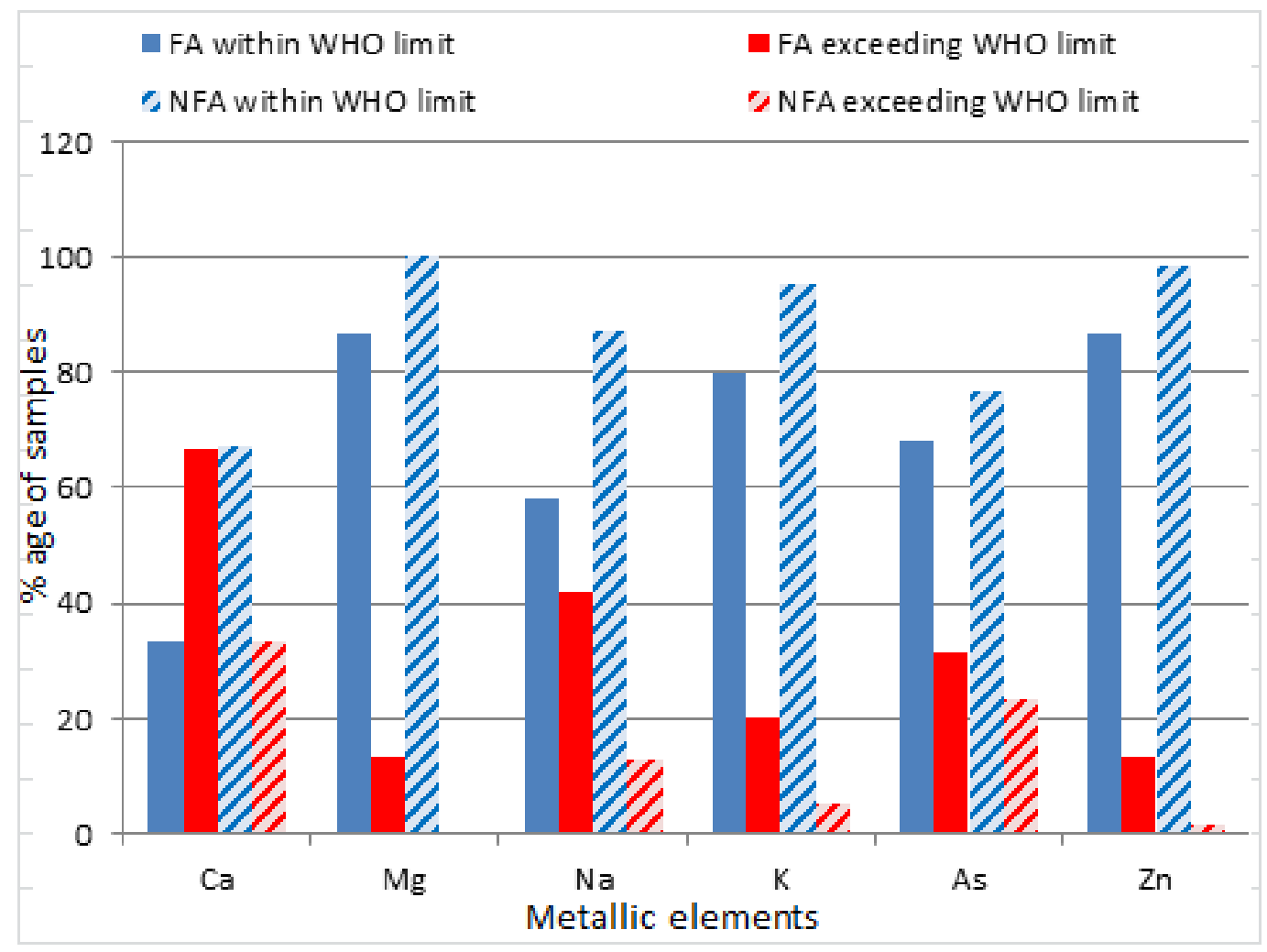

Figure 2. Comparison of water quality indicators in FA and NFA.

\section{Physico-chemical investigation}

Physical and aesthetic parameters including color, taste and turbidity of most of the water samples were not objectionable with the exception of a few having saline taste. Turbidity of water samples ranged from 0.2-3.5 NTU which was in agreement to WHO permissible limit of 5 NTU. Measurement of $\mathrm{pH}$ value (7.02-8.37) was also within WHO permissible limits of 6.5-8.5.

$\mathrm{EC}$ is the measure of ions concentration, their mobility in water Tecnología y ciencias del agua, ISSN 2007-2422, 11(5), 274-297. DOI:10.24850/j-tyca-2020-05-07 
and is an indication of dissolved ionizable solids. In present study EC ranged from 478-6335 $\mu \mathrm{S} / \mathrm{cm}$ in FA and $391-5152 \mu \mathrm{S} / \mathrm{cm}$ in NFA samples which indicated that FA have higher level of ionic concentration due to excessive dissolve solids. Alkalinity is also an important parameter of water quality. Mean value of alkalinity in FA and NFA samples was 295.5 and $248.9 \mathrm{mg} / \mathrm{l}$, respectively. Chloride are present naturally in water, but higher content may incorporate saline taste, create problems in throat and digestive system along with causing corrosion (Khan et al., 2000). Chloride varied from 31.5-1575 and 24.5-427 mg/l in FA and NFA samples, respectively.

In $\mathrm{FA}, \mathrm{SO}_{4}$ varied from 28 to $1230 \mathrm{mg} / \mathrm{l}$ and overall $65 \%$ water samples were having high concentration of $\mathrm{SO}_{4}$ as compared to WHO permissible limit whereas in NFA $35 \%$ samples were having $\mathrm{SO}_{4}$ content on higher side. Total hardness is combination of $\mathrm{Ca}, \mathrm{Mg}, \mathrm{Fe}, \mathrm{Cl}$ and $\mathrm{SO}_{4}$ concentrations and its high level may instigate heart diseases in residents (Jamshidzadeh \& Mirbagheri, 2011). Analysis data revealed that 53 and $15 \%$ sites in FA and NFA, respectively carried hardness higher than WHO guideline value of $500 \mathrm{mg} / \mathrm{l}$. Total dissolved solids (TDS) indicate the ability of water to dissolve a wide range of minerals and salts such as salts of $\mathrm{Na}, \mathrm{K}, \mathrm{Ca}, \mathrm{Cl}, \mathrm{SO}_{4}, \mathrm{NO}_{3}, \mathrm{Mg}$ and bicarbonates etc. Findings of the present study showed that 60 and $16 \%$ water samples in FA and NFA, respectively have high value of TDS than WHO permissible limit of $1000 \mathrm{mg} / \mathrm{l}$. Taste, hardness, corrosion properties and tendency to incrustation are associated with high TDS values in drinking water (WHO, 2004).

\section{Essential metals}


Present data indicated that 20 and 5\% water samples possessed $\mathrm{K}$ concentration higher than WHO guideline limit in FA and NFA, respectively. Potassium is an important micronutrient for living organisms which plays an important role in the metabolism process of animals. But, excess amount of $\mathrm{K}$ in the drinking water may lead towards nervous and digestive systems disorder. In FA samples $\mathrm{Na}$ ranged from 26-1 $000 \mathrm{mg} / \mathrm{l}$ whereas in NFA samples it varied from 27 to $410 \mathrm{mg} / \mathrm{l}$. Overall 42 and $13 \%$ water samples in FA and NFA, respectively were having high $\mathrm{Na}$ content. The high concentration of $\mathrm{Na}$ impart taste to the water and make it unfit for drinking purpose and leads to cardiovascular diseases, hypertension and high blood pressure (Azizullah et al., 2011). Calcium being the basic structural component of teeth, bones and soft tissues is involved in different metabolic processes of the body. Calcium content in analyzed samples varied from very low ( $8 \mathrm{mg} / \mathrm{l}$ ) to very high (416 $\mathrm{mg} / \mathrm{I}$ ) and in total 66.3 and $33 \%$ water samples have high level of $\mathrm{Ca}$ in FA and NFA, respectively. Magnesium is also an important essential element required by body for cardiac and vascular functions. Analysis data showed that $\mathrm{Mg}$ in only $13 \%$ FA water samples was higher than guideline value.

\section{Trace elements}


It is believed that due to interactions of hydrological cycle and the biosphere and geosphere, the groundwater sources used for drinking purpose generally contain natural organic matter (NOM) but during rainy season and floods its amount increases much more in surface and groundwater which changes organoleptic characteristics of water like taste, smell and color. Due to presence of NOM in water, oxidation of iron is inhibited by reducing it from $\mathrm{Fe}^{+3}$ to $\mathrm{Fe}^{+2}$, and as a result iron content in water is increased. Furthermore, literature supported the increase in concentration of iron due to anthropogenic activities and land run off, as elevated concentration of iron was observed during monsoon and rainy seasons (Idoko, 2010). Present study showed high level of iron in FA as $66.7 \%$ water samples were having Fe value greater than permissible limit (Figure 3).

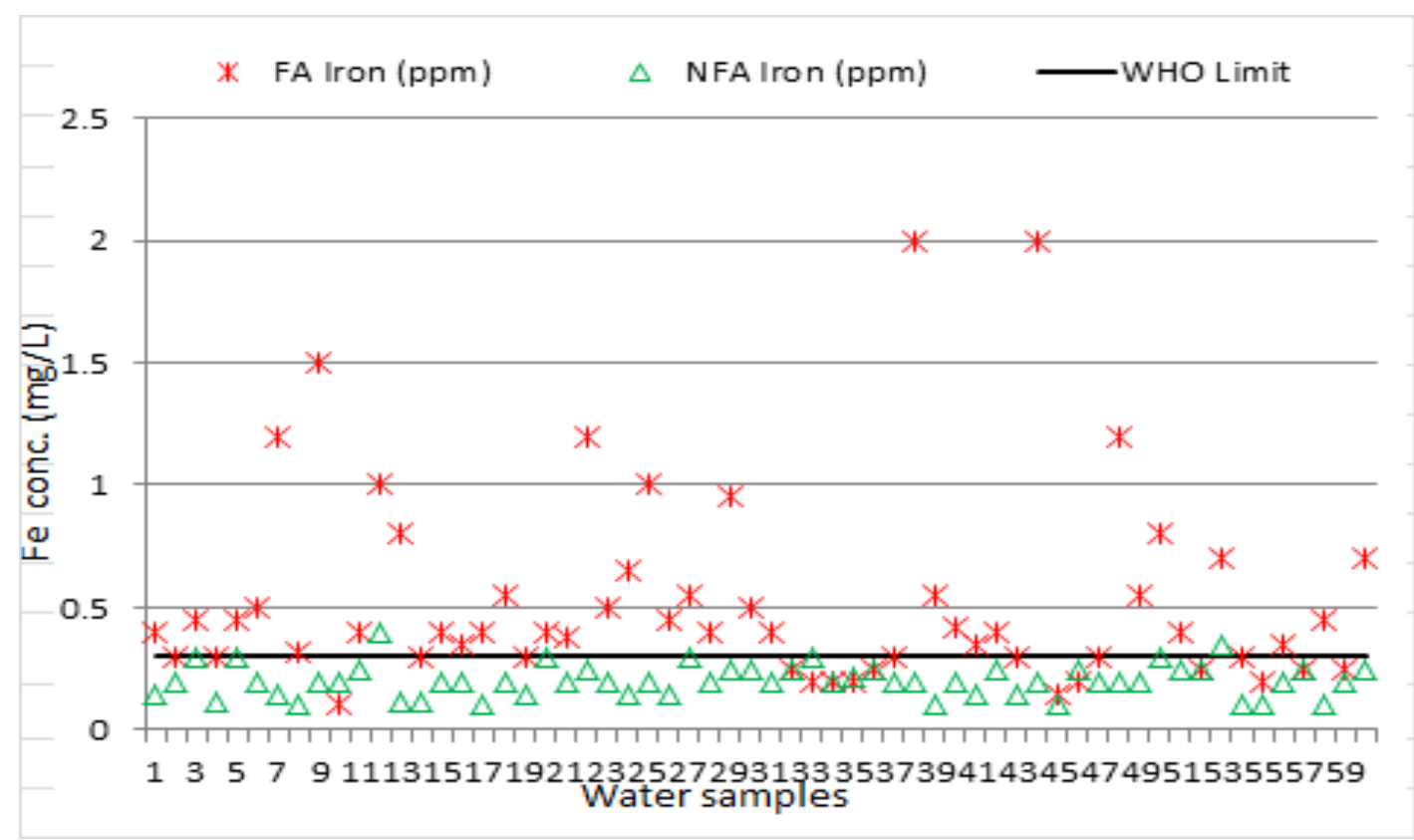

Figure 3. Comparison of Fe content in FA and NFA with WHO GVs.

Normally, drinking water seldom contains $\mathrm{Zn}$ above $0.1 \mathrm{mg} / \mathrm{L}$. Tecnología y ciencias del agua, ISSN 2007-2422, 11(5), 274-297. DOI:10.24850/j-tyca-2020-05-07 
Concentration of $\mathrm{Zn}$ higher than $3 \mathrm{mg} / \mathrm{l}$ (as $\mathrm{ZnSO}_{4}$ ) can impart an undesirable astringent taste to water. In present study, Zn content was higher in 13.3 and $1.7 \%$ water samples in FA and NFA, respectively. High concentration of $\mathrm{Zn}$ may be attributed to galvanized plumbing material usually used for boring purpose. Arsenic contamination of drinking water is a severe public health issue for Pakistan like other South Asian countries. Present study showed that 31.7 and $23.3 \%$ water samples possessed higher As in FA and NFA, respectively. It is well documented that dermatological symptoms such as melanosis (change pigmentation) and keratosis (rough, dry, papular skin lesions) have been identified in people who are exposed to chronic As poisoning through drinking water (Rahman, Ng, \& Naidu 2009b).

\section{Microbiological monitoring}

Microbial analysis data revealed that 41.7 and $8.3 \%$ water samples in FA and NFA, respectively have been contaminated with faecal coliform micro-organism which shows high level of contamination in FA schools (Figure 1). Saeed and Attaullah (2014) reported that drinking water was highly polluted with total colifoms and fecal coliforms in floodaffected areas of Charsadda and Nowshera (Saeed \& Attaullah, 2014).

\section{Health risk assessment}


Chronic daily intake (CDI) and health risk index (HRI) (chronic and carcinogenic effects) is calculated on the basis of As and other trace elements' concentration in drinking water (Kavcar, Sofuoglu, \& Sofuoglu, 2009). In present study, health risk assessment due to high concentration of $\mathrm{As}, \mathrm{Fe}$ and $\mathrm{Zn}$ in groundwater was carried out by measuring CDI and HRI values as shown in Table 3.

Table 3. Presentation of metallic elements in FA and NFA samples.

\begin{tabular}{|c|c|c|c|c|c|c|c|}
\hline & & \multicolumn{2}{|l|}{ As } & \multicolumn{2}{|l|}{$\mathbf{F e}$} & \multicolumn{2}{|l|}{$\mathbf{Z n}$} \\
\hline & & FA & NFA & $\overline{F A}$ & NFA & FA & NFA \\
\hline \multirow{3}{*}{ CDI } & Mean & 0.116 & 0.089 & 0.008 & 0.003 & 0.026 & 0.019 \\
\hline & Min. & 0.021 & 0.014 & 0.003 & 0.003 & 0.009 & 0.009 \\
\hline & Max. & 0.566 & 0.688 & 0.061 & 0.012 & 0.128 & 0.098 \\
\hline \multirow{3}{*}{ HRI } & Mean & 0.388 & 0.297 & 1.17E- 05 & 4.51E-06 & $8.68 \mathrm{E}-05$ & $6.45 \mathrm{E}-05$ \\
\hline & Min. & 0.071 & 0.046 & 4.37E- 06 & 4.37E- 06 & $3.06 \mathrm{E}-05$ & $3.06 \mathrm{E}-05$ \\
\hline & Max. & 1.886 & 2.294 & $8.74 \mathrm{E}-05$ & $1.75 \mathrm{E}-05$ & $4.28 E-04$ & $3.26 \mathrm{E}-04$ \\
\hline
\end{tabular}

Calculated CDI value for As, Fe and $\mathrm{Zn}$ in FA and NFA samples ranged from $0.021-0.566 \& 0.014-0.688,0.003-0.061 \& 0.003-0.012$ and 0.009-0.128 \& 0.009-0.098 $\mu \mathrm{g} \cdot \mathrm{kg}^{-1} \cdot \mathrm{day}^{-1}$, respectively. HRI value for As ranged from 0.071-1.886 and 0.046-2.294 for FA and NFA, respectively and overall 35\% water samples in FA and 23\% in NFA have HRI > 1. HRI for Fe and Zn were less than 1 in both FA and NFA samples. HRI calculations showed that trace elements in groundwater of public schools of district Sanghar were found in order of As $>\mathrm{Zn}>\mathrm{Fe}$. 


\section{Tecnología y Ciencias $₫$ Agua}

2020, Instituto Mexicano de Tecnología del Agua Open Access bajo la licencia CC BY-NC-SA 4.0 (https://creativ ecommons.org/licenses/by-nc-sa/4.0/)

Groundwater samples having HRI $>1$ highlight future consumer's health risk associated with intake of this water for drinking purpose. Literature shows high to very high carcinogenic and non-carcinogenic health risk for adults and children associated with elevated As concentration in drinking water and its correlation with Fe and other heavy metals (Van Halem et al., 2010).

\section{Conclusion}

Physico-chemical and microbiological analysis revealed that there was high level of microbial contamination in public schools of District Sanghar as $47 \%$ water samples were loaded with faecal coliform bacteria which may pose serious health threat to the healthy lives of young students. The study also showed that a large number of sampling sites were polluted with physico-chemical parameters like $\mathrm{Ca}$, hardness, $\mathrm{Na}, \mathrm{K}, \mathrm{Cl}, \mathrm{SO}_{4}, \mathrm{As}, \mathrm{Fe}$ and TDS. Net result of present study is that most of the waterborne diseases prevailing in the flooded region are due to consumption of contaminated water. A concrete policy should be devised to address post-flood environmental effects on life and human health so that safety from hazardous effects associated with bacterial contamination and elevated concentration of toxic components may be ensured. 


\section{Acknowledgements}

The authors of this paper acknowledge the efforts of PCRWR, Sargodha staff for their cooperation in water analysis.

\section{Conflict of interest}

There is no conflict of interest among the authors.

\section{References}

Alamgir, A., Khan, M. A., Schilling, J., Shaukat, S. S., \& Shahab, S. (2016). Assessment of groundwater quality in the coastal area of Sindh province, Pakistan. Environmental Monitoring and Assessment, 188, 1-13.

APHA, American Public Health Association. (2005). Standard methods for the examination of water and wastewater (21 $1^{\text {st }}$ ed.). Washington, DC, USA: American Public Health Association, American Water Works Association, Water Environment Federation.

Azizullah, A., Khattak, M. N. K., Richter, P., \& Häder, D. P. (2011). Water pollution in Pakistan and its impact on public health-a review. Environment International, 37, 479-497.

Baig, S., Xu, X., \& Khan, R. (2012). Microbial water quality risks to public health: Potable water assessment for a flood-affected town in northern Pakistan. Rural and Remote Health, 12, 3-2.

Djaouda, M., Njiné, T., Liang, S., Menye, D. E., Gaké, B., Togouet, S. H. Z., \& Nola, M. (2014). Bacteriological quality of well waters in Garoua, North Cameroon. Water Quality, Exposure and Health, 6, 161-176. 
Idoko, O. M. (2010). Seasonal variation in iron in rural groundwater of Benue State, Middle Belt, Nigeria. Pakistan Journal of Nutrition, 9, 892-895.

Jamshidzadeh, Z., \& Mirbagheri, S. (2011). Evaluation of groundwater quantity and quality in the Kashan Basin, Central Iran. Desalination, 270, 23-30.

Kavcar, P., Sofuoglu, A., \& Sofuoglu, S. C. (2009). A health risk assessment for exposure to trace metals via drinking water ingestion pathway. International Journal of Hygiene and Environmental Health, 212, 216-227.

Khan, A., Haq, I., Khan, W., Akif, M., Khan, M., \& Riaz, M. (2000). Quality characteristics of potable water of Mardan city (Pakistan) and surrounding areas. Journal of Chemical Society of Pakistan, 22, 87-93.

Khan, F. A., Ali, J., Ullah, R., \& Ayaz, S. (2013). Bacteriological quality assessment of drinking water available at the flood affected areas of Peshawar. Toxicological \& Environmental Chemistry, 95, 14481454.

Khan, S., Rehman, S., Khan, A. Z., Khan, M. A., \& Shah, M. T. (2010). Soil and vegetables enrichment with heavy metals from geological sources in Gilgit, northern Pakistan. Ecotoxicologyand Environmental Safety, 73, 1820-1827.

Khan, S., Shahnaz, M., Jehan, N., Rehman, S., Shah, M. T., \& Din, I. (2013). Drinking water quality and human health risk in Charsadda district, Pakistan. Journal of Cleaner Production, 60, 93-101.

Malik, M. A., Azam, E. M., \& Saboor, A. (2010). Water quality status of 


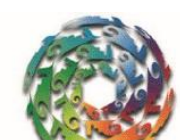

Ciencias $\stackrel{\sim}{\Im}$ Agua
2020, Instituto Mexicano de Tecnología del Agua

Open Access bajola licencia CC BY-NC-SA 4.0 (https://creativ ecommons.org/licenses/by-nc-sa/4.0/)

Upper KPK and Northern Areas of Pakistan (Report No. 142). Peshawar, Pakistan: Water Resources Research Center, Peshawar, Ministry of Science and Technology.

Memon, M., Soomro, M. S., Akhtar, M. S., \& Memon, K. S. (2011). Drinking water quality assessment in Southern Sindh (Pakistan). Environmental Monitoring and Assessment, 177, 39-50.

Mohsin, M., Safdar, S., Asghar, F., \& Jamal, F. (2013). Assessment of drinking water quality and its impact on residents health in Bahawalpur City. International Journal of Humanities and Social Science, 3, 114-128.

Oyem, H. H., Oyem, I. M., \& Usese, A. I. (2015). Iron, manganese, cadmium, chromium, zinc and arsenic groundwater contents of Agbor and Owa communities of Nigeria. Springer Plus, 4, 104.

Rahman, M. M., Naidu, R., \& Bhattacharya, P. (2009a). Arsenic contamination in groundwater in the Southeast Asia region. Environmental Geochemistry and Health, 31, 9-21.

Rahman, M. M., Ng, J. C., \& Naidu, R. (2009b). Chronic exposure of arsenic via drinking water and its adverse health impacts on humans. Environmental Geochemistry and Health, 31, 189-200.

Saeed, T. U., \& Attaullah, H. (2014). Impact of extreme floods on groundwater quality (in Pakistan). British Journal of Environment and Climate Change, 4, 133.

Sarfraz, M., Sultana, N., Jamil, M., \& Ashraf, R. (2016). Investigation of portable groundwater quality and health risk assessment of selected trace metals in flood affected areas of district Rajanpur, Pakistan. Journal of Environment \& Analytical Chemistry, 3, 183.

Sarfraz, M., Sultana, N., \& Jamil, M. (2018a). Groundwater quality and 
health risk assessment in rural areas of district Jaffarabad, Baluchistan (Pakistan). Pakistan Journal of Analytical \& Environmental Chemistry, 19(1), 129-135.

Sarfraz, M., Sultana, N., \& Tariq, M. I. (2018b). Assessment of groundwater quality and associated health risks in rural areas of Sindh (Pakistan). Studia Ubb Chemia, 63(1), 125-136.

Shah, M., Ara, J., Muhammad, S., Khan, S., \& Tariq, S. (2012). Health risk assessment via surface water and sub-surface water consumption in the mafic and ultramafic terrain, Mohmand agency, Northern Pakistan. Journal of Geochemical Exploration, $118,60-67$.

Thivya, C., Chidambaram, S., Thilagavathi, R., Nepolian, M., \& Adithya, V. (2014). Evaluation of drinking water quality index (DWQI) and its seasonal variations in hard rock aquifers of Madurai district, Tamilnadu. International Journal of Advanced Geosciences, 2, 48-52.

USEPA, United States Environmental Protection Agency. (2002). Method 1603: Escherichia coli (E. coli) in water by membrane filtration using modified membrane-thermotolerant Escherichia coli agar (modified $m T E C$ ). Recovered from https://www.epa.gov/sites/production/files/201508/documents/method_1603_2009.pdf

Van Halem, D., Olivero, S., De Vet, W., Verberk, J., Amy, G., \& van Dijk, J. (2010). Subsurface iron and arsenic removal for shallow tube well drinking water supply in rural Bangladesh. Water Research, 4, 5761-5769.

Venkatramanan, S., Chung, S., Kim, T., Prasanna, M., \& Hamm, S. (2015). Assessment and distribution of metals contamination in 
groundwater: A case study of Busan City, Korea. Water Quality, Exposure and Health, 7, 219-225.

WHO, World Health Organization. (2004). Guidelines for drinking-water quality: recommendations, World Health Organization, Geneva. 